\title{
Resistance to Meloidogyne paranaensis in wild Coffea arabica
}

\author{
Marc Boisseau ${ }^{1}$, Jamel Aribi ${ }^{2}$, Fábio Rodriguez de Sousa ${ }^{3}$, Regina M.D.G. Carneiro ${ }^{3}$ \& François \\ Anthony ${ }^{2}$
}

${ }^{1}$ Centre de Coopération Internationale en Recherche Agronomique pour le Développement-CIRAD, Station de Neufchâteau Sainte Marie, 97130 Capesterre Belle-Eau, Guadeloupe, France; ${ }^{2}$ Institut de Recherche pour le Développement - IRD, 34394 Montpellier Cedex 5, France; ${ }^{3}$ Embrapa Recursos Genéticos e Biotecnologia, 708849-970 Brasilia, DF, Brazil

Author for correspondence: Regina M.D.G. Carneiro, e-mail: recar@cenargen.embrapa.br

\begin{abstract}
Nine accessions of wild Coffea arabica from Ethiopia were evaluated for resistance to Meloidogyne paranaensis. Two wellcharacterized susceptible and resistant cultivars were used as comparative controls. The experiments were conducted in a growth chamber using a clonal population of M. paranaensis (esterase phenotype P1) originating from Brazil. Resistance and susceptibility to the nematode were evaluated using the number of nematodes (eggs and J2) per plant, number of nematodes per gram of root and the reproduction factor (RF). All wild coffee accessions expressed a resistance response to $M$. paranaensis similar to that of the resistant control Nemaya (RF < 1.0). These results provide coffee breeders with material whose resistance can be transferred into commercial cultivars.

Keywords: coffee, root-knot nematode, pathogenicity.

\section{RESUMO}

Avaliação da resistência de cafeeiros silvestres (Coffea arabica) a Meloidogyne paranaensis

Foram avaliados quanto à resistência a Meloidogyne paranaensis, nove acessos de cafeeiros silvestres incluindo dois cultivares bem caracterizados como testemunhas de suscetibilidade e resistência. Os experimentos foram realizados sob condições controladas em câmara de crescimento, utilizando uma população clonal de M. paranaensis (fenótipo de esterase P1), proveniente do Brasil. A resistência e a suscetibilidade ao nematóide foram avaliadas com base no número total de nematóides por planta (ovos + J2) e por grama de raiz e no fator de reprodução (FR). Todos os acessos mostraram resposta à infecção por M. paranaensis similar à da testemunha resistente (FR $<1,0)$. Com esses resultados, novos materiais, cuja resistência pode ser transferida aos cultivares comerciais, ficam disponíveis para os fitomelhoristas.
\end{abstract}

Palavras-chave: café, nematóide das galhas, patogenicidade.

Root-knot nematodes (Meloidogyne spp.) are a major constraint on coffee production in most countries worldwide (Campos \& Villain, 2005; Campos \& Silva, 2008). Seventeen species of Meloidogyne are acknowledged as pathogens to coffee (Carneiro \& Cofcewicz, 2008). Economic losses due to root-knot nematodes vary considerably depending on the species involved and its distribution. Some Meloidogyne species induce numerous galls but only cause a 10 to $20 \%$ drop in yield (Bertrand et al., 1997). Other species cause serious damage in plantations, destroying up to $80 \%$ of the root system within five years of planting (Bertrand \& Anthony, 2008).

Meloidogyne paranaensis (Carneiro et al., 1996) is one of the most destructive root-knot species on coffee. This species induces foliar necrosis, reduces growth, causes leaf drop and a general plant decline, and can even cause plant death (Campos \& Villain, 2005). M. paranaensis is widely distributed in Brazil and Guatemala, where coffee represents an important source of income and employment. M. paranaensis was mistaken for M. incognita for more than 20 years (Carneiro et al., 1996). Consequently, publications prior to 1996, and a few since, refer to an isolate collected in Guatemala at the beginning of the 1990s as Meloidogyne sp. or $M$. incognita, when it was in fact identified as $M$. paranaensis (Carneiro et al., 2004). Although the populations of M. paranaensis from Brazil and from Guatemala presented different esterase phenotypes Est P1 and Est $\mathrm{P} 2$, respectively, they are very closely related in molecular and morphological approaches (Carneiro et al., 2004). Nevertheless, these two populations presented different physiological behavior in relation to resistant tomato with Mi gene: P2 parasitized the resistant tomato and P1 did not (Carneiro, R.M.D.G., pers. inform.). Among the nonchemical methods available to control root-knot nematodes in coffee, the use of resistant cultivars is considered one of the most effective and environmentally safe alternatives. 
Work on coffee resistance to M. paranaensis (Est P2) began in Guatemala and resistant accessions were identified among cultivars of Coffea canephora Pierre ex. Froehn. (Anzueto et al., 2001; Bertrand et al., 2000). In C. arabica L., all cultivars were susceptible to M. paranaensis (Est P2), whereas some wild coffee accessions from Ethiopia, the center of origin of the species, were resistant (Anzueto et al., 2001). These findings have increased the interest in wild coffee for breeding purposes, which have greater genetic diversity than commercial cultivars (Anthony et al., 2001) and also resistance to M. arabicida López \& Salazar,1989 whose distribution is restricted to Costa Rica (Bertrand et al., 2002b). The objective of this paper was to screen wild C. arabica for resistance to M. paranaensis (Est P1) from Brazil.

The study was conducted in the Nematology laboratory of the French Agricultural Research Centre for International Development (CIRAD) at Montpellier, France. The plant material consisted of seven wild coffee accessions (Table 1) from Ethiopia (Guillaumet \& Hallé, 1978) and two well-characterized coffee cultivars (Caturra and Nemaya), used as controls. Seven accessions had been reported as being resistant to $M$. paranaensis isolate from Guatemala (Anzueto et al., 2001). The commercial cultivar Caturra (Carvalho et al., 1991) served as the susceptible $M$. paranaensis control (Anzueto et al., 2001). The rootstock cultivar Nemaya served as the $M$. paranaensis resistant control (Bertrand et al., 2002a). Seedlings of Nemaya were produced in seed gardens in the Coffee Research Centre of Guatemala (ANACAFE) (Bertrand et al., 2002a). Seedlings were used because $C$. arabica is not polymorphic (Anthony et al., 2001; 2002) and is self-fertile (Carvalho et al., 1991). Seedlings of the wild accessions and Caturra were provided

TABLE 1 - Origin of the wild coffee accessions collected in Ethiopia by ORSTOM in 1966 (Guillaumet and Hallé, 1978). The "Et" accessions are conserved in the CATIE field genebank at Turrialba and the "Ar" accessions in the IRD greenhouse at Montpellier

\begin{tabular}{lllll}
\hline \hline & \multicolumn{2}{l}{ Ethiopian collection site } & Material & Previous \\
\cline { 2 - 3 } Accession & Village & Province & evaluated & Evaluation* \\
\hline Et-15 & Gimma-Goré & Kefa & Seedling & Resistant \\
Et-25 & Tippi & Illubabor & Seedling & Resistant \\
Et-25B & Tippi & Illubabor & Seedling & Resistant \\
Et-32B & Tippi & Illubabor & Seedling & \\
Et-52 & Bonga & Kefa & Seedling & \\
Et-57 & Bonga & Kefa & Seedling & Resistant \\
Ar 57 & Bonga & Kefa & Cutting & Resistant \\
Et-59 & Bonga & Kefa & Seedling & Resistant \\
Ar 59 & Bonga & Kefa & Cutting & Resistant \\
\hline
\end{tabular}

* using a Meloidogyne paranaensis isolate Est P2 from Guatemala (Anzueto et al., 2001) by the Tropical Agricultural Research and Higher Education Centre (CATIE) in Costa Rica. Cuttings of two Ethiopian accessions (Ar 57, Ar 59) were also prepared from a coffee genebank maintained by the IRD in Montpellier. These accessions have a common origin in Ethiopia with the Et57 and Et-59 accessions conserved in the field genebank of CATIE. Seedlings and cuttings were cultivated in 300 $\mathrm{cm}^{3}$ plastic pots containing 4:1 (v/v) sterilized soil and fine sand in a growth chamber at $25^{\circ} \mathrm{C}\left( \pm 1^{\circ} \mathrm{C}\right)$ and $70 \%$ relative humidity. Five plants of each accession were evaluated. A clonal population of $M$. paranaensis was established from a single egg mass of nematodes originally collected from coffee in Apucarana (Paraná State, Brazil) and then maintained in culture by Embrapa Recursos Genéticos e Biotecnologia. A clonal population ensures repeatability of the evaluations (Bertrand \& Anthony, 2008). This clonal population was cultured in a growth chamber on Caturra coffee plants. When the plants were three months old (two pairs of fully-expanded leaves), single plants were inoculated with about 750 eggs and second-stage juveniles (J2) into $1-\mathrm{cm}$ deep holes around the collar region. Four months later, plants were removed carefully from the pots. The root systems were gently washed with tap water and weighed. Nematodes were extracted by maceration, centrifugation and flotation (Coolen \& d'Herde, 1972). The final population density $(\mathrm{Pf}=$ number of eggs $+\mathrm{J} 2)$ was quantified using a Peter slide under LM and nematode reproduction factors $(\mathrm{RF}=\mathrm{Pf} / 750)$ were calculated. RFs were characterized as showing resistance $(\mathrm{RF}<1.0)$ or susceptibility $(\mathrm{RF}>1.0)$ (Oostenbrink, 1966). Data of root weight and nematode population were analyzed by one-way analyses of variance (ANOVA) using Statistica version 7.1 software () StatSoft, Inc.). Mean values were compared between accessions and controls with Duncan's test at $\mathrm{P}=0.01$.

ANOVA revealed that the root weights were different $(\mathrm{P}=0.015)$ among the material evaluated, and the means formed two groups according to Duncan's test (Table 2). This justified the use of the number of nematodes per gram of root additionally to the total number of nematodes extracted per plant (final population $=$ FP). Differences were shown by analyses of variance for the FP $(\mathrm{P}<0.021)$ and the number of nematodes per gram of $\operatorname{root}(\mathrm{P}<0.0008)$. The FP of the resistant 'Nemaya' was 233 and 6,700 on the susceptible 'Caturra' (Table 2). On average, the resistant control contained about 30 times fewer nematodes than the susceptible plant. Nematode per gram of root had a lower coefficient of variation than the FP $(26.1 \%$ vs. $42.7 \%$ respectively). The wild accessions had FP from 67 to 477 (Table 2). The accessions' response to M. paranaensis was similar to 'Nemaya', limiting nematode reproduction to low levels.

At least one nematode was extracted from each plant, indicating that all the accessions supported reproduction of M. paranaensis. Similar residual populations have been observed in coffee inoculated with M. exigua (Gonçalves \& Pereira, 1998; Anthony et al., 2005) and M. incognita 
TABLE 2 - Evaluation of resistance to Meloidogyne paranaensis (Est P1) from Brazil in wild coffee accessions as compared to the susceptible 'Caturra' and resistant 'Nemaya' cultivars. Values in a column with the same letter are not different $(\mathrm{P}=0.01)$ by the Duncan test

\begin{tabular}{lcccc}
\hline \hline $\begin{array}{c}\text { Cultivar or } \\
\text { accession }\end{array}$ & $\begin{array}{c}\text { Root weight } \\
(\mathbf{g})\end{array}$ & $\begin{array}{c}\text { Nematodes / } \\
\text { plant }\end{array}$ & $\begin{array}{c}\text { Nematodes / } \\
\text { g root }\end{array}$ & $\begin{array}{c}\text { Reproduction } \\
\text { Factor }\end{array}$ \\
\hline Caturra & $6.4^{\mathrm{ab}}$ & $6,700^{\mathrm{a}}$ & $1,013^{\mathrm{a}}$ & $8.9^{\mathrm{a}}$ \\
Nemaya & $5.0^{\mathrm{b}}$ & $233^{\mathrm{b}}$ & $58^{\mathrm{b}}$ & $0.3^{\mathrm{b}}$ \\
Et-15 & $7.3^{\mathrm{ab}}$ & $477^{\mathrm{b}}$ & $61^{\mathrm{b}}$ & $0.6^{\mathrm{b}}$ \\
Et-25 & $5.6^{\mathrm{b}}$ & $167^{\mathrm{b}}$ & $31^{\mathrm{b}}$ & $0.2^{\mathrm{b}}$ \\
Et-25B & $4.8^{\mathrm{b}}$ & $200^{\mathrm{b}}$ & $50 \mathrm{~b}$ & $0.3^{\mathrm{b}}$ \\
Et-32B & $4.8^{\mathrm{b}}$ & $180^{\mathrm{b}}$ & $36^{\mathrm{b}}$ & $0.2^{\mathrm{b}}$ \\
Et-52 & $4.7^{\mathrm{b}}$ & $100^{\mathrm{b}}$ & $21^{\mathrm{b}}$ & $0.1^{\mathrm{b}}$ \\
Et-57 & $5.9^{\mathrm{ab}}$ & $67^{\mathrm{b}}$ & $12^{\mathrm{b}}$ & $0.1^{\mathrm{b}}$ \\
Et-59 & $6.3^{\mathrm{ab}}$ & $167^{\mathrm{b}}$ & $27^{\mathrm{b}}$ & $0.2^{\mathrm{b}}$ \\
Ar 57 & $8.9^{\mathrm{ab}}$ & $320^{\mathrm{b}}$ & $37^{\mathrm{b}}$ & $0.4^{\mathrm{b}}$ \\
Ar 59 & $10.6^{\mathrm{a}}$ & $88^{\mathrm{b}}$ & $8^{\mathrm{b}}$ & $0.1^{\mathrm{b}}$ \\
\hline
\end{tabular}

(Gonçalves et al., 1996). This suggests an underlying mechanism of defense response after infection, which allows reproduction of a small number of nematodes.

These results confirmed a previous screening of resistance in wild coffee from Ethiopia using a $M$. paranaensis Est P2 isolate from Guatemala (Anzueto et al., 2001). New sources of resistance (Et-32B and Et-52) were identified. This identification has increased the set of resistant genotypes available to coffee breeding programs. Accessions resistant to $M$. paranaensis were collected in the provinces of Kefa and Illubabor, which constitute the center of diversity for $C$. arabica. Root-knot nematode resistance may be a common trait in wild coffee and widely distributed among wild plants. The coffee genetic resources of the study are conserved in several coffee genebanks worldwide (Brazil, Colombia, Ivory Coast, Cameroon, Tanzania, Kenya and Madagascar) and are thus available for the scientific community (Anthony et al., 2007).

Resistance to $M$. paranaensis can be easily transferred into susceptible cultivars by making controlled hybridizations (Bertrand \& Anthony, 2008). All the accessions from the study except one (Et-25B) have been used as male parents and crossed with commercial cultivars Caturra and Catuai in order to produce $\mathrm{F}_{1}$ hybrids (Bertrand et al., 2005). Breeders should be able to produce coffee hybrids that have resistance genes to $M$. paranaensis and to $M$. arabicida from the wild coffee genitor, and to $M$. exigua from an introgressed line like Iapar 59, which has inherited the resistance gene Mex-1 from C. canephora (Bertrand et al., 2001). In a few years, it may be possible to offer coffee growers cultivars that are resistant to a range of root-knot nematodes, greatly reducing yield losses and nematicide usage.

\section{ACKNOWLEDGEMENTS}

The authors are grateful to Centro Agronómico Tropical de Investigación y Enseñanza - CATIE, Costa Rica, for providing seeds of Caturra and Ethiopian accessions, and to Asociación Nacional de Café en Guatemala - ANACAFE for those of the rootstock Nemaya.

\section{REFERENCES}

Anthony F, Bertrand B, Quiros O, Wilches A, Lashermes P, Berthaud J, Charrier A (2001) Genetic diversity of wild coffee (Coffea arabica L.) using molecular markers. Euphytica 118:5365.

Anthony F, Combes MC, Astorga C, Bertrand B, Graziosi G, Lashermes P (2002) The origin of cultivated Coffea arabica L. varieties revealed by AFLP and SSR markers. Theoretical and Applied Genetics 104:894-900.

Anthony F, Dussert S, Dulloo E (2007) The coffee genetic resources. In: Engelmann F, Dulloo E, Astorga C, Dussert S., Anthony $\mathrm{F}$ (Eds.) Complementary strategies for ex situ conservation of coffee (Coffea arabica L.) genetic resources. A case study in CATIE, Costa Rica. Topical reviews in Agricultural Biodiversity, Biodiversity International, Rome. pp. 12-22

Anthony F, Topart P, Martinez A, Silva M, Nicole M (2005) Hypersensitive-like reactions conferred by the Mex-1 resistance gene against Meloidogyne exigua in coffee. Plant Pathology 54:476-482.

Anzueto F, Bertrand B, Sarah JL, Eskes AB, Decazy B (2001) Resistance to Meloidogyne incognita in Ethiopian Coffea arabica accessions. Euphytica 118:1-8.

Bertrand B, Aguilar G, Bompard E, Rafinon A, Anthony F (1997) Comportement agronomique et résistance aux principaux 
déprédateurs des lignées de Sarchimor et Catimor au Costa Rica. Plantations, Recherche, Développement 4:312-321.

Bertrand B, Anthony F (2008) Genetics of resistance to rootknot nematode nematodes (Meloidogyne spp.) and breeding. In: Souza RM (Ed.) Plant-Parasitic Nematodes of coffee. Dordrecht. Springer. pp. 165-190.

Bertrand B, Anthony F, Lashermes P (2001) Breeding for resistance to Meloidogyne exigua of Coffea arabica by introgression of resistance genes of C. canephora. Plant Pathology 50:637-643.

Bertrand B, Anzueto F, Moran MX, Eskes AB, Etienne H (2002a) Creation and diffusion by somatic embryogenesis of the 'Nemaya' rootstock variety (Coffea canephora) in Central America. Plantations, Recherche, Développement, special issue «Research and coffee growing»:pp.105-107.

Bertrand B, Etienne H, Cilas C, Charrier A, Baradat P (2005) Coffea arabica hybrid performance for yield, fertility and bean weight. Euphytica 141:255-262.

Bertrand B, Peña Durán M X, Anzueto F, Cilas C, Etienne H, Anthony F, Eskes, AB (2000) Genetic study of Coffea canephora coffee tree resistance to Meloidogyne incognita nematodes in Guatemala and Meloidogyne sp. nematodes in El Salvador for selection of rootstock varieties in Central America. Euphytica 113:79-86.

Bertrand B, Ramirez G, Topart P, Anthony F (2002b) Resistance of cultivated coffee (Coffea arabica and C. canephora) to corky-root caused by Meloidogyne arabicida and Fusarium oxysporum under controlled and field conditions. Crop Protection 21:713-719.

Campos VP, Silva JRC (2008) Management of Meloidogyne spp. in coffee plantations. In: Souza RM (Ed.) Plant-Parasitic Nematodes of coffee. Dordrecht. Springer. pp. 149-164.

Campos VP, Villain L (2005) Nematode parasites of coffee and cocoa. In: Luc M, Sikora RA, Bridge J (Eds.) Plant parasitic nematodes in Subtropical and Tropical Agriculture, 2nd edition. Wallingford, UK. CAB International. pp. 529-579

Carneiro RMDG, Carneiro RG, Abrantes IMO, Santos MSNA, Almeida MRA (1996). Meloidogyne paranaensis n. sp. (Nemata: Meloidogynidae), a root-knot nematode parasitizing coffee in Brazil. Journal of Nematology 28:177-189.

Carneiro RMDG, Cofcewicz ET (2008) The taxonomy of Coffee -Parasitic root-knot nematodes, Meloidogyne spp. In: Souza RM (Ed.) Plant-Parasitic Nematodes of coffee. Dordrecht. Springer. pp. 87-122.

Carneiro RMDG, Tigano MS, Randig O, Almeida MRA, Sarah, JL (2004) Identification and genetic diversity of Meloidogyne spp. (Tylenchida: Meloidogynidae) on coffee from Brazil, Central America and Hawaii. Nematology 6:287-298.

Carvalho A, Medina Filho HP, Fazuoli LC, Guerreiro Filho O, Lima MMA (1991) Aspectos genéticos do cafeeiro. Revista Brasileira de Genética 14:135-183.

Coolen WA, D'Herde CJ (1972) A method for the quantitative extraction of nematodes from plant tissue. Ghent State Agricultural Research Centre.

Gonçalves W, Barbosa LCC, Lima MMA, Silvarolla MB (1996) Patogenicidade de Meloidogyne exigua e M. incognita raça 1 a mudas de cafeeiros. Bragantia 55:89-93.

Gonçalves W, Pereira A (1998) Resistência do cafeeiro a nematóides IV- Reação de cafeeiros derivados do Híbrido de Timor a Meloidogyne exigua. Nematologia Brasileira 22:39-50.

Guillaumet JL, Hallé F (1978) Echantillonnage du matériel récolté en Ethiopie. Bulletin IFCC 14:13-18.

Oostenbrink M (1966) Major characteristics of the relation between nematodes and plants. Mededel Landbouwhogeschool Wageningen 66:1-44.

Received 3 July 2008 - Accepted 16 February 2009 - TPP 8067 Associated Editors: Ricardo M. Souza, Vicente P. Campos 